\title{
Cloning of ribosomal ITS PCR products creates frequent, non-random chimeric sequences - a test involving heterozygotes between Gymnopus dichrous taxa I and II
}

\author{
Karen W. Hughes', Samuel D. Morris², Ana Reboredo-Segovia ${ }^{3}$ \\ I Ecology and Evolutionary Biology, University of Tennessee, Knoxville, Tennessee 379202130 Ervin Dr., \\ Nashville, TN 370753 Erasmus Mundus Master's Program in Tropical Biodiversity and Ecosystems, Université \\ Pierre et Marie Curie - UPMC Paris, France
}

Corresponding author: Karen W. Hughes (khughes@utk.edu)

Academic editor: R. Henrik Nilsson | Received 16 April 2014 | Accepted 6 June 2015 | Published 19 June 2015

Citation: Hughes KW, Morris SD, Reboredo-Segovia A (2015) Cloning of ribosomal ITS PCR products creates frequent, non-random chimeric sequences - a test involving heterozygotes between Gymnopus dichrous taxa I and II. MycoKeys 10 : 45-56. doi: 10.3897/mycokeys.10.5126

\begin{abstract}
Gymnopus dichrous exists in the southern Appalachians (USA) as two distinct entities with essentially identical nuclear ribosomal ITS1 sequences but differing ITS2 and LSU sequences (for convenience, called G. dichrous I and II). F $_{1}$ ITS heterozygotes between the two are routinely collected from nature. Cloning of ITS PCR products from $\mathrm{F}_{1}$ heterozygotes produced sequences of both parental haplotypes but also numerous chimeric sequences $(21.9 \%)$. The location of template switching was non-random leading to recovery of the same chimera several times and the chimeric region varied from $45 \mathrm{bp}$ to $300 \mathrm{bp}$. By comparison, single-basidiospore isolates from heterozygote $F_{1}$ fruitbodies showed no recombinant haplotypes within the ITS + LSU span and clones derived from $\mathrm{P}_{1}$ homozygotes were identical to the $\mathrm{P}_{1}$ parent. Thus, chimeric sequences are likely an artifact of the PCR-cloning process and not a consequence of natural recombination events found in nature, nor are they due to hidden existing variation within the ribosomal repeat. Chimeras and PCR-induced mutations are common in cloned PCR products and may result in incorrect sequence information in public databases.
\end{abstract}

\section{Key words}

Basidiomycete fungi, chimera, hybrid, monokaryons, recombination, ribosomal repeat

Copyright Karen W. Hughes et al. This is an open access article distributed under the terms of the Creative Commons Attribution License (CC BY 4.0), which permits unrestricted use, distribution, and reproduction in any medium, provided the original author and source are credited. 


\section{Introduction}

Sequence chimeras are common when pooled DNA s are co-amplified by a PCR process (Edgar et al. 2011; Judo et al. 1998; Jumpponen 2007; Meyerhans et al. 1990; Odelberg et al. 1995; Qiu et al. 2001a; Smyth et al. 2010; Tedersoo et al. 2014; Wang and Wang 1997). There has been speculation that chimeras may be the result of incomplete extension of PCR products which subsequently act as primers for the next amplification cycle and, in fact, there seems to be a reduction in chimeric PCR products when extension times are increased (Meyerhans et al. 1990; Qiu et al. 2001a; Smyth et al. 2010; Thompson et al. 2002) or by optomizing the PCR protocol (Qiu et al. 2001b; Wang and Wang 1997). Odelberg et al. (1995) however, demonstrated that chimeras can be generated in a single round of PCR amplification in the absence of heat denaturation and re-annealing which suggests that some polymerase template switching may occur. They demonstrated that template switching was reduced several fold (but not eliminated) by fixing templates to streptavidin magnetic beads.

The overall frequency of chimeras in published studies is unknown. In a study of fungal ITS amplicons derived from soil samples using a PCR/cloning process (O'Brian et al. 2005), 5\% were chimeric as determined by an ascomycete/basidiomycete discontinuity between ITS1 and ITS2 regions. Smaller chimeras between related taxa would not have been detected in this study [see later detection of a chimera in this data set by Ryberg et al. (2008)]. For nSSU sequences, the proportion of chimeric sequences can be extensive (Ashelford et al. 2005; Ashelford et al. 2006; Fonseca et al. 2012; Haas et al. 2011; Wang and Wang 1997) leading to 'false diversity estimates and false novel taxa. Fonseca et al (2012) demonstrated that nuclear SSU chimeras were produced at high levels during the PCR-process when mixed templates were present. Interestingly, their results with a nematode population demonstrated that chimera formation is higher in species-diverse PCR pools than in pools that are genetically less diverse but that the breakpoints were in regions of sequence similarity.

Most programs for checking and removing chimeric sequences were designed for 16S ribosomal sequences. DECIPHER (Wright et al. 2012) (http://decipher.cee.wisc. edu/index.html) for bacterial $16 \mathrm{~S}$ sequences searches for sets of short fragments that are uncommon in the phylogenetic group where the sequence is classified, but frequent in other phylogenetic groups. This depends on a robust pre-existing data set. UCHIME (Edgar et al. 2011), a chimera check program, is best when two known parental sequences and a high-quality reference database that is chimera free are available. Bellerophon uses a partial treeing analyses to detect $16 \mathrm{~S}$ chimeras (Huber et al. 2004). Other chimera checking programs are available [see Fonseca et al. (2012) for discussion].

Nilsson et al. (2012) note the high incidence of ITS chimeras in public ITS databases and suggest a mechanism for identifying them by Blast mismatches between the ITS1 and ITS2 regions and by exploring long branches in phylogenetic trees. They comment that the most frequent site for exchange between two similar templates in a PCR reaction is in the first part of the highly conserved $5.8 \mathrm{~S}$ segment. An open source chimera checker for the ITS region has been developed and is available at http://www. 
emerencia.org/chimerachecker.html (Nilsson et al. 2010). Using chimera checker to evaluate 12300 sequences, $1.5 \%$ were identified as chimeric sequences. To better facilitate ITS-based molecular identification of fungi for the scientific community, the UNITE database was established to provide reliable documented ITS sequences for the fungal community (Kóljalg et al. 2013; Nilsson et al. 2015) and a reference set of ITS sequences, each representing a species hypothesis is available in several formats including UCHIME (Nilsson et al. 2015), available at https://unite.ut.ee/repository. php\#uchime.

With the establishment of the ribosomal ITS as the fungal barcode (Schoch et al. 2012), and the identification of highly heterozygous fungal ITS sequences that require cloning to resolve, it becomes increasingly important to understand the consequences of cloning PCR products from mixed templates including cloned PCR products generated during environmental sampling. Divergent Gymnopus dichrous ITS2 haplotypes provide an appropriate experimental system with which to explore this issue.

Gymnopus dichrous is a small, saprobic mushroom commonly found on oak bark and other woody debris in mid-summer in the southern Appalachian Mountains (USA). ITS sequencing identified two ITS subgroups of this mushroom called for convenience G. dichrous I and II. Gymnopus dichrous I and II differ in the ITS2 region (10\% divergence) but there are no consistent or significant bp differences between $G$. dichrous I and II ITS1 or $5.8 S$ regions (average divergence $=0.29 \%$ between the $G$. dichrous I and II ITS1 region, $0 \%$ in the 5.8 s region). Homozygous collections for $G$. dichrous I and $G$. dichrous II were collected in the southern Appalachian Mountains and were designated as parental genotypes $\left(\mathrm{P}_{1}\right)$. Fruitbodies that were ITS hybrids between $G$. dichrous I and $G$. dichrous II were also been collected and were designated as $\mathrm{F}_{1}$ hybrids (first filial generation as used in standard genetic crosses). For $\mathrm{F}_{1}$ hybrids, several indels in the ITS2 region obscured electropherograms and prevented recovery of the parental ITS sequences during Sanger sequencing. Cloning of the ITS1-5.8SITS2 PCR product was required to recover individual contributing haplotypes, however, a significant portion of recovered haplotypes were chimeric sequences.

Cloned ITS sequences were compared to $\mathrm{P}_{1}$ (parental/ homozygote) ITS sequences of Gymnopus dichrous I and II to identify chimeric and non-chimeric sequences. Below, we examine chimeras derived from cloned $G$. dichrous heterozygotes and show that they can be small, frequent and non-random. We also provide evidence that putative chimeras were not due to natural meiotic recombination or variation in the ribosomal repeat.

\section{Methods and materials}

Collections. Gymnopus dichrous and G. subnudus are often collected as the same entity and are morphologically difficult to separate. Both are variable in morphology. Putative Gymnopus dichrous collections were made in the field using known morphological and environmental characteristics [e.g., small (ca. $5 \mathrm{~cm}$ in height) brown mushrooms, often 
with a darker, compressed, stem base and growing on wood, usually but not exclusively on oak bark]. Of 116 collections of putative $G$. dichrous, 16 were $G$. dichrous I-II hybrids (Table 1). Collections are archived in TENN-Fungi.

Single basidiospore isolation. Single-basidiospore isolates (SBIs) were obtained from fresh spore drops as described in Gordon and Petersen (1992). Monokaryon status of SBI cultures was determined microscopically by lack of clamp connections.

PCR and Cloning procedures. Cloning was carried out using Promega's pGEMT easy kit and M109 Competent cells according to manufacturer's directions (Promega). Sanger sequencing of ITS-cloned products was performed as described in Hughes et al. (Hughes et al. 2009).

PCR of the nuclear ribosomal ITS area was performed using primers ITS1F (Gardes and Bruns 1993) and ITS4 (White et al. 1990) for all collections in this study. PCR parameters for ITS amplification were $3 \mathrm{~min}$ at $94^{\circ} \mathrm{C}$ followed by 34 cycles of $94{ }^{\circ} \mathrm{C}$ for $1 \mathrm{~min}, 55^{\circ} \mathrm{C}$ for $1 \mathrm{~min}, 72^{\circ} \mathrm{C}$ for $1 \mathrm{~min}$ and a final extension of $72{ }^{\circ} \mathrm{C}$ for $3 \mathrm{~min}$. Each $50 \mu \mathrm{l}$ PCR reaction contained $24.25 \mu$ sterile $\mathrm{ddH}_{2} \mathrm{O}, 10 \mu \mathrm{l}$ of $5 \mathrm{X}$ PCR buffer (Promega Corporation, 2800 Woods Hollow Road, Madison, WI 53711 USA a), $2.5 \mu \mathrm{l}$ 5\% DMSO (Sigma-Aldrich Company, St. Louis, MO, USA), $6 \mu \mathrm{l}$ of 25 $\mathrm{mM} \mathrm{Mg}=3 \mathrm{mM}$ (Promega), $4 \mu \mathrm{l}$ of $100 \mathrm{mM}$ dNTP mix (Promega), $1 \mu \mathrm{l}$ each of two primers $(10 \mu \mathrm{M})$ and $0.25 \mu \mathrm{l} \mathrm{Taq}$ polymerase (Promega). Sequencing of the 5' end of the nuclear ribosomal RNA large subunit gene was performed for single spore isolates only and used primers LR0R and LR5 (Vilgalys and Hester 1990). Parameters for LSU amplification are the same as for ITS except the extension time at $72{ }^{\circ} \mathrm{C}$ was $1.5 \mathrm{~min}$.

Identification of template switching regions. There are 25 regions of sequence mismatch within $G$. dichrous I and $G$. dichrous II (Fig. 1, red text) which were used to identify apparent template switching. The first difference at ITS2 position 15 and the $1 \mathrm{bp}$ indel at position 24 were used to establish whether the 5' end of ITS2 represented G. dichrous I or G. dichrous II. Base pair 31 (A or G) is variable within the G. dichrous I population and when it is an adenine residue, it can be used as an additional marker. Clones exhibiting template switching were identified by an observed sequence change from $G$. dichrous I to G. dichrous II (or vice-versa) between bases 25 and 332. Four discontinuities were observed in the data set between bp15 and bp25. In two cases, bp25 and an adenine/guanine base pair at bp 31 were used to identify the 5' end of the clone as $G$. dichrous I or II. In the other two cases, bp25 and bp71 were used to identify the 5 ' end of the clone. The discontinuities may be due to template switching or to PCR generated mutation. We note that rare PCR-induced base pair mutations could affect determination of the correct template switching point.

DNA folding. Potential DNA folding of the ITS2 region for $G$. dichrous I and II exemplars was estimated at $72{ }^{\circ} \mathrm{C}$ (extension phase of PCR) using the MFOLD web server (http://mfold.rna.albany.edu/?q=mfold/DNA-Folding-Form) with a $\mathrm{MgCl}$ setting of $3 \mathrm{mM}$ (Zuker 2003) and $0 \mathrm{mM} \mathrm{Na}$.

Chi square analysis. The ITS 2 region was divided into 25 segments of varying length between bases 25 and 332. Each segment was flanked by a sequence difference between $G$. dichrous I and II that was informative for diagnosing template switching. 


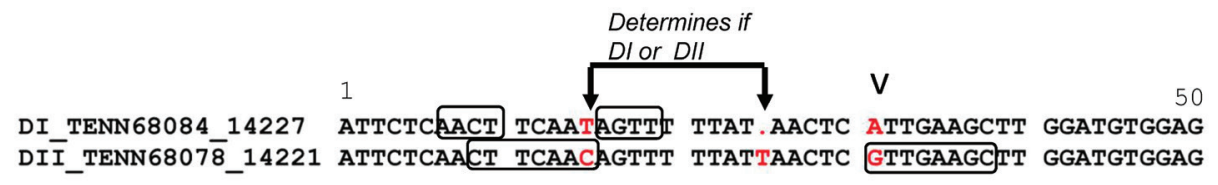

51

100

DI_TENN68084_14227 GTTTGCTGGC GTCTTAGATG TCCGGCTCCT CTTAAATGCA TTAGTGGAAC DIİ_TENN68078_14221 GTTTGCTGGC GTCTTAGATG TTCGGCTCCT CTTAAATGCA TTAGTGGAC $\longrightarrow$ ts=5 $\stackrel{1}{\longrightarrow} \longrightarrow$

101

150

DI_TENN68084_14227 CCGTTTGTTG ACCATCCIT GGTETGATAA TTATCTACAC TTTGGAATAA

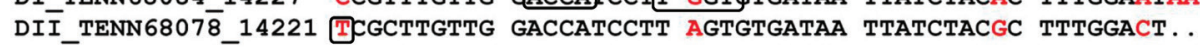

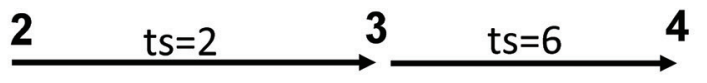

151

200

DI_TENN68084_14227 TCTGADAGCC CDATTGACT TTTCTCAGTT ACTEGTTGGG GCTTTGCA. .

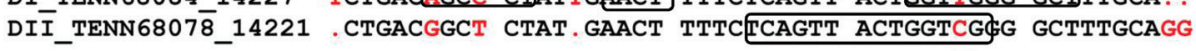
$\longrightarrow$ ts $=5 \stackrel{5}{\longrightarrow}$

201

250

DI_TENN68084_14227 TTAATTTGCT TTGCCTGTTT CCTTCAGTGG CTGGTTGGGA CTCTGCATTA DII_TENN68078_14221 CCGATTGCT TTGTCTGTTT TCTTEATAA CTGGTTGGGA CTTTGCACTA $\stackrel{\mathrm{ts}=1}{\longrightarrow}$

251

300

DI_TENN68084_14227 GTTTGCTTTG TYTGTTC..T GTTCATTAGA GTAGGAAAAT CTGCTTTCTA

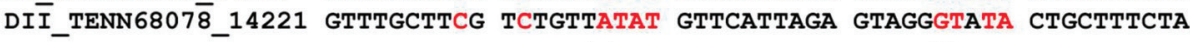

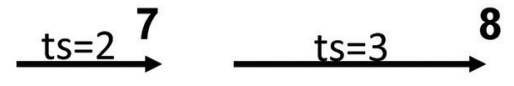

301

332

DI TENN68084 14227 ACTGTCTGTG TATTCGGACG ATTTATTGAC CA DII_TENN68078__14221 ACCGTSTGTG TATGCGGACA ACTTATTGAC CA

Figure I. The ITS2 region of two haplotypes of Gymnopus dichrous: Haplotypes DI (represented by TENN68084) and DII (represented by TENN68078). The TC pair at position 15 and the indel at position 25 were used to determine which the haplotype was represented by the 5 ' end of a cloned sequence. Bases in red are points where DI and DII haplotypes differ in sequence and were used to determine if template switching had occurred in a cloned PCR product. Eight base pairs at which template switching can be detected are indicated by numbers 1-8. The possible area in which template switching (ts) could have occurred is indicated by vertical arrows and the number of observed template switching events is given above the vertical arrow. Bases that may be involved in intra-strand base pairing as determined by MFOLD are outlined with black boxes. Ambiguity codes indicate intraspecific variation. 
Table I. Distribution of ITS sequences from clones of Gymnopus dichrous I-II heterozygotes.

\begin{tabular}{|c|c|c|c|c|c|c|}
\hline $\begin{array}{l}\text { Collection number } \\
\text { of heterozygote }\end{array}$ & $\begin{array}{l}\text { Herbarium } \\
\text { Number }^{1}\end{array}$ & $\begin{array}{l}\text { GenBank } \\
\text { Numbers }\end{array}$ & $\begin{array}{l}\text { Number } \\
\text { of clones }\end{array}$ & $\begin{array}{l}\text { G. dichrous I } \\
\text { (\# recovered) }\end{array}$ & $\begin{array}{l}\text { G. dichrous II } \\
\text { (\# recovered) }\end{array}$ & $\begin{array}{c}\text { G. dichrous } \\
\text { chimeras } \\
\text { (\# recovered) }\end{array}$ \\
\hline WS9223 & DEWV9223 & & 7 & 2 & 2 & 3 \\
\hline WRWV03-989 & DEWV4744 & & 6 & 3 & 3 & 0 \\
\hline WRWV04-322 & DEWV5833 & & 6 & 2 & 3 & 1 \\
\hline 10454 & TENN58148 & & 8 & 4 & 2 & 2 \\
\hline 10455 & TENN58149 & & 2 & 2 & 0 & 0 \\
\hline 11785 & TENN60014 & $\begin{array}{l}\text { JF313671- } \\
\text { JF313672 }\end{array}$ & 4 & 3 & 1 & 0 \\
\hline 11814 & TENN60027 & $\begin{array}{l}\text { JF313673- } \\
\text { JF313677 }\end{array}$ & 5 & 2 & 2 & 1 \\
\hline 13361 & TENN61624 & $\begin{array}{c}\text { JF313678- } \\
\text { JF313693 }\end{array}$ & 13 & 5 & 6 & 2 \\
\hline 14061 & TENN67807 & & 8 & 2 & 4 & 2 \\
\hline 14094 & TENN67843 & & 8 & 2 & 3 & 3 \\
\hline 14111 & TENN67859 & & 8 & 3 & 4 & 1 \\
\hline 14226 & TENN68083 & & 8 & 2 & 3 & 3 \\
\hline 14230 & TENN68090 & & 8 & 1 & 4 & 3 \\
\hline 14237 & TENN68092 & & 7 & 1 & 4 & 2 \\
\hline 14247 & TENN68105 & & 16 & 4 & 9 & 3 \\
\hline 14248 & TENN68106 & & 14 & 6 & 6 & 2 \\
\hline Totals & & & 128 & $44=34.37 \%$ & $56=43.75 \%$ & $28=21.88 \%$ \\
\hline
\end{tabular}

${ }^{1}$ TENN-F-XXXXXX is abbreviated as TENNXXXXXX

For each segment, the number of template switching events was recorded, ranging from zero to six. These constituted observed values. Expected values were based on a null hypothesis of random template switching (each base has an equal probability of template switching).

\section{Results and discussion}

The proportion of ITS chimeras obtained from PCR amplification of the ITS regions of $G$. dichrous I-II heterozygotes is given in Table 1 . Of 128 clones from $\mathrm{F}_{1}$ heterozygotes, $28(21.9 \%)$ were chimeric in the ITS2 region. The number of clones representing non-chimeric ITS sequences was unequally distributed between $G$. dichrous I and II. From $\mathrm{F}_{1}$ heterozygotes, $34.4 \%$ of the clones were $G$. dichrous I sequences and $43.75 \%$ were $G$. dichrous II sequences.

The distribution of template switch points resulting in chimeras was not random along the ITS2 region $($ Chi square $=35.72, \mathrm{P}<0.05)$. Of 25 possible diagnostic base pair sites, template switching was observed between only 8 points (Fig. 1) and the most frequent template switching (six events) occurred within a very short span of bases, bases 122-138 creating 6 identical chimeric sequences. Two regions of 5 tem- 
plate switching events were also observed (Fig. 1). It should be noted that the exact point at which template switching occurred cannot be determined in regions where $G$. dichrous I and II have identical sequence but is between the last 5' diagnostic base pair difference between $G$. dichrous I and II and the diagnostic base pair at which template switching occurred (Fig. 1, horizontal arrows). The possibility of identical chimeras occurring in GenBank and thus being interpreted as valid taxa was noted by Nilsson et al. (2012).

The non-random nature of template switching would suggest that some stable mechanism influences template switching. We investigated the possibility that secondary structure formation during the PCR process might lead to non-random chimera formation, perhaps by briefly stalling taq polymerase transcription at the point of secondary folding and allowing template switching. Ribosomal ITS2 RNA is known to have secondary structure at normal cellular temperatures and conditions (Joseph et al. 1999; Krüger and Gargas 2004; Krüger and Gargas 2008). We wondered if the formation of DNA secondary structure in the ITS2 region might affect chimera formation. Using MFOLD (Zuker 2003) we examined secondary structure of ITS2 DNAs at $72{ }^{\circ} \mathrm{C}$ (extension phase). At $72{ }^{\circ} \mathrm{C}$, MFOLD predicted stable secondary structure in both $G$. dichrous I and $G$. dichrous II templates. For $G$. dichrous I, 4 possible folding configurations were reported at increasing levels of free energy (dG). The folding configuration with the lowest free energy is mapped to the sequence in Fig. 1. For $G$. dichrous II, a single folding configuration was reported. This is also mapped to Fig. 1. We note that factors other than the ITS2 sequence itself influence RNA folding.

The most frequent template switching occurred in a region between bases 122 and 138. This region overlaps and follows a small area of folding (a 4bp neck and 4bp loop) in $G$. dichrous I templates. The region between 140 and 200 is involved in complex folding patterns that are not consistent from model to model but present in all models. Five template switching events occur in this region. Between bases 200 and the end of the template at base 332, there is no consistently predicted secondary structure and fewer template switching events. Thus there is a loose agreement between secondary structure and regions of template switching but we cannot conclude cause and effect.

The size of detectable chimeras varied from chimeras occurring at the $5^{\prime}$ end of the ITS2 sequence (approximately 300bp) to those occurring near the 3 ' end (45bp). Chimeras occurring between bp 15 and bp 25 would not have been recorded as such by our procedure but may have occurred ( 4 discontinuities may be due to template switching or to PCR generated mutation-see methods). We note that there is an area of secondary structure which overlaps bp15 and could be involved in template switching.

Areas where G. dichrous DI and DII differ extensively including indels (bases 147151, 198-205) do not seem to be involved in template switching. This has been noted in other studies as well (Fonseca et al. 2012; Haas et al. 2011).

To evaluate whether cloning simply uncovered existing variation in the ribosomal repeat region (Lindner and Banik 2011), we sequenced the ITS plus LSU region of single basidiospore isolates (SBIs) derived from F1 heterozygotes (Table 2). SBIs of $\mathrm{F}_{1}$ spores were either $G$. dichrous I or II and did not show any evidence of meiotic 
Table 2. Concatinated single basidiospore isolate (SBI) ITS + LSU sequences.

\begin{tabular}{l|c|c|c|c|c}
\hline $\begin{array}{l}\text { Collection number of } \\
\text { heterozygote }\end{array}$ & $\begin{array}{c}\text { Herbarium } \\
\text { Number }\end{array}$ & $\begin{array}{c}\text { Number } \\
\text { of SBIs }\end{array}$ & G. dichrous I & G. dichrous II & $\begin{array}{c}\text { Number of meiotic } \\
\text { recombinants } \\
\text { In ITS+LSU }\end{array}$ \\
\hline $\mathbf{F}_{\mathbf{1}}$ G. dichrous I-II heterozygotes \\
\hline 14111 & TENN67859 & 11 & 5 & 6 & 0 \\
\hline 14226 & TENN68083 & 8 & 5 & 3 & 0 \\
\hline 14237 & TENN68092 & 5 & 1 & 4 & 0 \\
\hline Totals & & $11(44 \%)$ & $13(52 \%)$ & 0 \\
\hline $\mathbf{P}_{\mathbf{1}} \boldsymbol{G}$. dichrous I homozygotes & & & 0 \\
\hline 13716 & TENN65070 & 10 & 10 & 0 & 0 \\
\hline 14232 & TENN68091 & 10 & 10 & 0 & 0 \\
\hline $\mathbf{P}_{\mathbf{1}}$ G. dichrous II homozygotes & No specimen & 4 & 0 & 4 & \\
\hline Braaton
\end{tabular}

recombination between ITS + LSU types I and II. We further examined SBI sequences from two collections of $G$. dichrous I (Table 2) and found no evidence that any $G$. dichrous II sequence elements were present in the ribosomal repeat. Finally, we cloned PCR products from three collections of $G$. dichrous I (TENN68152-8 clones, TENN67834-7 clones, TENN69091-8 clones) and again found no evidence for the presence of $G$. dichrous II sequence elements. We conclude that there is no current evidence in $G$. dichrous that cloning is recovering existing intragenomic variation in the ribosomal repeat but cannot exclude that possibility. Results reported as intragenomic variation in Laetiporus cincinnatus by Lindner and Banik (2011) could be due to differences in one or more ribosomal repeats but could also be explained if the sampled fruitbody was a hybrid and the two parental haplotypes and resulting chimeras were recovered.

\section{Conclusions}

Chimeras are common in cloned PCR products and tend to obscure contributing parental haplotypes, thus potentially creating errors in DNA sequence repositories. In this study, we show:

1. Template switching is non-random. Of 25 possible markers where ITS2 sequences of $G$. dichrous I and II differ, only 8 show template switching and template switching is higher in specific regions of the ITS2 sequences. The non-random nature of chimeras could lead to the misinterpretation of chimeras as parental haplotypes when the same chimera is recovered multiple times.

2. There is a loose correlation between areas predicted to form secondary structure and regions where template switching is high. We conclude that formation of secondary structure may affect template switching but speculate that secondary 
structure formation could either enhance or repress template switching, depending on location and the size of the stem-loop structure.

3. Chimeras occurring near the end of a template may be short and thus not easily detected.

4. Chimeras are not due to recovery of underlying variability in the ribosomal repeat in this system. The origins of chimeras remain obscure and may be due to multiple factors.

5. Chimera control should be exercised in environmental sampling studies and taxonomic studies wherever possible in order to minimize problems with persistent errors in sequence data repositories.

\section{Acknowledgements}

This study was supported by NSF DEB1144974 to R. H. Petersen, KWH, and Brian O’Meara. We thank reviewers Henrik Nilsson, Martin Ryberg Leho Tedersoo, Shawn Brown and an anonymous reviewer for their careful reviews, comments and suggestions.

\section{References}

Ashelford KE, Chuzhanova NA, Fry JC, Jones AJ, Weightman AJ (2005) At Least 1 in $2016 \mathrm{~S}$ rRNA Sequence Records Currently Held in Public Repositories Is Estimated To Contain Substantial Anomalies. Applied and Environmental Microbiology 71: 7724-7736. doi: 10.1128/aem.71.12.7724-7736.2005

Ashelford KE, Chuzhanova NA, Fry JC, Jones AJ, Weightman AJ (2006) New screening software shows that most recent large 16S rRNA gene clone libraries contain chimeras. Appl Environ Microbiol, 5734-5741. doi: 10.1128/AEM.00556-06

Edgar RC, Haas BJ, Clemente JC, Quince C, Knight R (2011) UCHIME improves sensitivity and speed of chimera detection. Bioinformatics 27(16): 2194-2200. doi: 10.1093/ bioinformatics/btr381

Fonseca VG, Nichols B, Lallias D, Quince C, Carvalho GR, Power DM, Creer S (2012) Sample richness and genetic diversity as drivers of chimera formation in nSSU metagenetic analyses. Nucleic Acids Research 40: e66. doi: 10.1093/nar/gks002

Gardes M, Bruns TD (1993) ITS primers with enhanced specificity for basidiomycetes application to the identification of mycorrhizae and rusts. Mol Ecol 2: 113-118. doi: 10.1111/j.1365-294X.1993.tb00005.x

Gordon SA, Petersen RH (1992) Interbreeding populations of some Marasmius species. Mycologia 84: 204-208. doi: 10.2307/3760251

Haas BJ, Gevers D, Earl AM, Feldgarden M, Ward DV, Giannoukos G, Ciulla D, Tabbaa D, Highlander SK, Sodergren E, Methé B, DeSantis TZ, Consortium THM, Petrosino JF, Knight R, Birren BW (2011) Chimeric 16S rRNA sequence formation and detection in Sanger and 454-pyrosequenced PCR amplicons. Genome Research 21: 494-504. doi: $10.1101 /$ gr. 112730.110 
Huber T, Faulkner G, Hugenholtz P (2004) Bellerophon: a program to detect chimeric sequences in multiple sequence alignments. Bioinformatics 20: 2317-2319. doi: 10.1093/ bioinformatics/bth226

Hughes KW, Petersen RH, Lickey EB (2009) Using heterozygosity to estimate a percentage DNA sequence similarity for environmental species delimitation across basidiomycete fungi. New Phytologist 182: 795-798. doi: 10.1111/j.1469-8137.2009.02802.x

Joseph N, Krauskopf E, Vera MI, Michot B (1999) Ribosomal internal transcribed spacer 2 (ITS2) exhibits a common core of secondary structure in vertebrates and yeast. Nucleic Acids Research 27: 4533-4540. doi: 10.1093/nar/27.23.4533

Judo MSB, Wedel AB, Wilson C (1998) Stimulation and suppression of PCR-mediated recombination. Nucleic Acids Research 26: 1819-1825. doi: 10.1093/nar/26.7.1819

Jumpponen A (2007) Soil Fungal Communities Underneath Willow Canopies on a Primary Successional Glacier Forefront: rDNA Sequence Results Can Be Affected by Primer Selection and Chimeric Data. Microbial Ecology 53: 233-246. doi: 10.1007/s00248-004-0006-x

Kóljalg U, Nilsson RH, Abarenkov K, Tedersoo L, Taylor AFS, Bahram M, Bates ST, Bruns TD, Bengtsson-Palme J, Callaghan TM, Douglas B, Drenkhan T, Eberhardt U, Dueńas M, Grebenc T, Griffith GW, Hartmann M, Kirk PM, Kohout P, Larsson E, Lindahl BD, Lücking R, Martín MP, Matheny PB, Nguyen NH, Niskanen T, Oja J, Peay KG, Peintner U, Peterson M, Póldmaa K, Saag L, Saar I, Schüßler A, Scott JA, Senés C, Smith ME, Suija A, Taylor DL, Telleria MT, Weiss M, Larsson K-H (2013) Towards a unified paradigm for sequence-based identification of fungi. Molecular Ecology 22: 5271-5277. doi: $10.1111 / \mathrm{mec} .12481$

Krüger D, Gargas A (2004) The basidiomycete genus Polyporus - an emendation based on phylogeny and putative secondary structure of ribosomal RNA molecules. Feddes Repertorium 115: 530-546. doi: 10.1002/fedr.200311052

Krüger D, Gargas A (2008) Secondary structure of ITS2 rRNA provides taxonomic characters for systematic studies - a case in Lycoperdaceae (Basidiomycota). Mycological Research 112: 316-330. doi: 10.1016/j.mycres.2007.10.019

Lindner DL, Banik MT (2011) Intragenomic variation in the ITS rDNA region obscures phylogenetic relationships and inflates estimates of operational taxonomic units in genus Laetiporus. Mycologia 103: 731-740. doi: 10.3852/10-331

Meyerhans A, Vartanian J-P, Wain-Hobson S (1990) DNA recombination during PCR. Nucleic Acids Research 18: 1687-1691. doi: 10.1093/nar/18.7.1687

Nilsson RH, Tedersoo L, Abarenkov K, Ryberg M, Kristiansson E, Hartmann M, Schoch C, Nylande rJ, Bergsten J, Porter T, Jumpponen A, Vaishampayan P, Ovaskainen O, Hallenberg N, Bengtsson-Palme J, Eriksson K, Larsson K, Larsson E, Kóljalg U (2012) Five simple guidelines for establishing basic authenticity and reliability of newly generated fungal ITS sequences. Mycokeys 4: 37-63. doi: 10.3897/mycokeys.4.3606

Nilsson RH, Tedersoo L, Ryberg M, Kristiansson E, Hartmann M, Unterseher M, Porter TM, Bengtsson-Palme J, Walker DM, de Sousa F, Andres Gamper H, Larsson E, Larsson K-H, Kóljalg U, Edgar RC, Abarenkov K (2015) A Comprehensive, Automatically Updated Fungal ITS Sequence Dataset for Reference-Based Chimera Control in Environmental Sequencing Efforts. Microbes and Environments advpub. doi: 10.1264/jsme2.ME14121 
Nilsson RH, Veldre V, Hartmann M, Unterseher M, Amend A, Bergsten J, Kristiansson E, Ryberg M, Jumpponen A, Abarenkov K (2010) An open source software package for automated extraction of ITS1 and ITS2 from fungal sequences for use in high-throughput communitiy assays and molecular ecology. Fungal Ecology 3: 284-287. doi: 10.1016/j. funeco.2010.05.002

O’Brian HE, Parrent JL, Jackson JA, Moncalvo J-M, Vilgalys R (2005) Fungal community analysis by large scale sequencing of environmental samples. Applied and Environmental Microbiology 71: 5544-5550. doi: 10.1128/AEM.71.9.5544-5550.2005

Odelberg SJ, Weiss RB, Hata A, White R (1995) Template-switching during DNA synthesis by Thermus aquaticus DNA polymerase I. Nucleic Acids Research 23: 2049-2057. doi: 10.1093/nar/23.11.2049

Qiu X, Wu L, Huang H, McDonel PE, Palumbo AV, Tiedje JM, Zhou J (2001a) Evaluation of PCR-Generated Chimeras, Mutations, and Heteroduplexes with 16S rRNA Gene-Based Cloning. Appl Environ Microbiol 67: 880-887. doi: 10.1128/aem.67.2.880-887.2001

Qiu X, Wu L, Huang H, McDonel PE, Palumbo AV, Tiedje JM, Zhou J (2001b) Evaluation of PCR-Generated Chimeras, Mutations, and Heteroduplexes with 16S rRNA GeneBased Cloning. Applied and Environmental Microbiology 67: 880-887. doi: 10.1128/ aem.67.2.880-887.2001

Ryberg M, Nilsson RH, Kristiansson E, Töpel1 M, Jacobsson S, Larsson E (2008) Mining metadata from unidentified ITS sequences in GenBank: A case study in Inocybe (Basidiomycota). BMC Evolutionary Biology 8: 50. doi: 10.1186/1471-2148-8-50

Schoch CL, Seifert KA, Huhndorf S, Robert V, Spouge JL, Levesque CA, Chen W, Consortium FB (2012) Nuclear ribosomal internal transcribed spacer (ITS) region as a universal DNA barcode marker for Fungi. Proceedings of the National Academy of Sciences 109: 6241-6246. doi: 10.1073/pnas.1117018109

Smyth RP, Schlub TE, Grimm A, Venturi V, Chopra A, Mallal S, Davenport MP, Mak J (2010) Reducing chimera formation during PCR amplification to ensure accurate genotyping. Gene 469: 45-51. doi: 10.1016/j.gene.2010.08.009

Tedersoo L, Bahram M, Dickie IA (2014) Does host plant richness explain diversity of ectomycorrhizal fungi? Re-evaluation of Gao et al. (2013) data sets reveals sampling effects. Molecular Ecology 23: 992-995. doi: 10.1111/mec.12660

Thompson JR, Marcelino LA, Polz MF (2002) Heteroduplexes in mixed-template amplifications: formation, consequence and elimination by 'reconditioning PCR'. Nucleic Acids Research 30: 2083-2088. doi: 10.1093/nar/30.9.2083

Vilgalys R, Hester M (1990) Rapid genetic identification and mapping of enzymatically amplified ribosomal DNA from several Cryptococcus species. Journal of Bacteriology 172: 4238-4246.

Wang GC, Wang Y (1997) Frequency of formation of chimeric molecules as a consequence of PCR coamplification of $16 S$ rRNA genes from mixed bacterial genomes. Applied and Environmental Microbiology 63: 4645-4650.

White TJ, Bruns T, Lee S, Taylor J (1990) Amplification and direct sequencing of fungal ribosomal RNA genes for phylogenetics. In: Innis MA, Gelfand DH, Sninsky JJ, White TJ (Eds) PCR Protocols, A Guide to Methods and Applications. Academic Press, San Diego, 315-322. 
Wright ES, Yilmaz LS, Noguera DR (2012) DECIPHER, a Search-Based Approach to Chimera Identification for 16S rRNA Sequences. Applied and Environmental Microbiology 78: 717-725. doi: 10.1128/aem.06516-11

Zuker M (2003) Mfold web server for nucleic acid folding and hybridization prediction. Nucleic Acids Research 31: 3406-3415. doi: 10.1093/nar/gkg595 